\title{
Corporate Responsibility as The Legal Subject in Corruption Case to Ensure Legal Certainty
}

\author{
Erwin Satrio Wilogo \\ \{erwinwilogo71@gmail.com\} \\ Doctor of Law, Universitas Jayabaya, Jakarta, Indonesia
}

\begin{abstract}
Corporate criminal responsibility theoretically puts corporation as a subject of criminal law that can be accounted for according to criminal law. This position has not yet been sufficiently understood and taken into account in formulating criminal provisions against corporations, prosecution and punishment of corporations in criminal justice practices. The current regulations have not yet discussed the criminal liability of corporations, especially related to the guidelines for criminalizing corporations. This absence affects the prosecution and punishment of corporations. This descriptive analytical research employed normative juridical approach as the main approach, followed with statutory approach. Data were primary, secondary and tertiary legal materials which were qualitatively and normatively analyzed in a complete and systematic manner. It is confirmed in this research that there is no clear regulation concerning corporate crime in Indonesia in the Criminal Code. Nevertheless, the possibility of corporations committing criminal acts has been disseminated in various laws outside the Criminal Code, including the Law concerning the Eradication of Corruption. The formulation of the regulation is not supported by adequate formal law, but the absence has been compensated with the issuance of Perma No. 13 of 2016 concerning Procedures for Handling Corporate Crime. Unfortunately, the Perma is not a statutory level with the law, making it improper if the formulation of corporate crime in the regulation was only supported by formal law which level is lower than the law. This issue can be completely addressed if the Perma is upgraded to law or registered into the Draft Criminal Procedure Code that will be immediately applied.
\end{abstract}

Keywords: Corporation, Criminal Act of Corruption, Legal Certainty

\section{Introduction}

At the infancy of the subject of criminal law and criminal responsibility, it is universally recognized that a subject is a natural person. In law, a doctrine was generally accepted at that time, namely, universitas delinquere non potest, which meant that a corporation could not commit a criminal act. Von Savigny's view influences this that corporations as legal subjects that call a legal fiction accepted in civil law are inappropriate to be contested in the podium of the criminal law [1]. In criminal law, the existence of a criminal act must meet the requirements such as the presence of actus reus and men's rea and the application of principles of actus non facit reum, nisi men's sit rea. Therefore, only humans can commit a criminal act under the pretext that only humans err (men's rea or evil mind or evil will (evil mental attitude)). Although there was no recognition of the corporation as a subject of criminal law at that time, this does not mean that corporate crime has never occurred. According to J.E. Sahetapy, corporate crime is nothing new and often disguised in a novelty of shape and form. 
At present, the recognition of corporations as subjects of criminal law and criminal liability against corporations is absolute. In terms of domestic and international law, the provisions regarding corporations as criminal law subjects and their criminal liability are strictly regulated. Admittedly In Indonesian criminal law, although the current Criminal Code is derived from the 1886 Dutch Wetboek van Strafrecht based on the concordance principle and is intended only for private persons (natural persons) [2], and corporations are not yet included as subjects of criminal law. Criminal law outside the Criminal Code recognizes corporations as criminal law subjects, and corporations can be held accountable according to the criminal law.

The politics of criminal law in Indonesia shows the recognition of corporations as subjects of criminal law and corporate criminal liability, but it does not have a significant meaning for law enforcement on corporate crime. Until now, relatively few corporations have been prosecuted, tried, and accounted for based on criminal laws that regulate corporations as subjects of criminal law, such as under the Corruption Eradication Law, Money Laundering Law, Human Trafficking Law, and Law Environment. Several existing corporate criminal cases mostly concerned with pollution and/or environmental destruction and some in other fields.

Some examples are environmental pollution by PT Dongwoo Environmental Indonesia in Bekasi District, as decided in the Supreme Court decision Number 862 K/Special Law/2010 dated April 7, 2011, environmental pollution by Hotel Batam View Beach Resort, environmental pollution by PT Pacific Paint in Jakarta, the illegal sale of diesel fuel by the Singaporean company Marineriese Trading PTE.LTD. In these corporate criminal cases, most of those who were prosecuted and tried were the management and only in PT Dongwoo Environmental Indonesia, in which the corporation was both the defendant and convict represented by a natural person called Kim Young Woo. Eventually, the criminal verdict agreed to settle the case through a fine of Rp.650,000,000 and imprisonment for six months, although there is a problem here that prison confinement can only be imposed on a natural person instead of a corporation. In other corporate criminal cases that are prosecuted and put on trial, only the management is considered natural persons, while the actual corporation in its entirety does not stand in a trial.

Based on this, the problem arises: what is the status of the formulation of criminal liability policy for public corporations today? First, are those liabilities applied only to persons as the entity that can be held criminally responsible, or can they also be imposed on public corporations or public service institutions? Second, if criminal responsibility can be imposed on a public corporation, then in what ways can criminal responsibility be imposed on it? Third, what type of verdict imposed on public corporations to ensure legal certainty? Observing the nature of position and system within a public corporation that is certainly different from its private counterpart, the verdict designated to each then cannot be equated.

\section{Research Methods}

The method used in this research is descriptive-analytical with the main approach of normative juridical. In a normative juridical study, the use of a statute approach is a definite matter. Such certainty is due to the legal logic of normative legal research based on research conducted on existing legal materials. Although, for example, a study was conducted because it saw a legal vacuum, such a notion could be identified because there were already legal norms that required further regulation in positive law [3]. 


\section{Results and Discussion}

Until now, it is still delicate for the court to decide corporations as defendants and convicted persons in cases such as corruption, money laundering, trafficking in persons, even though these crimes were committed through or involving corporations. Corporate crimes mean the crimes are committed for the corporation's benefit, and thus the corporation should be prosecuted as a subject of a criminal act. The author has only found criminal acts in the environmental sector based on Law Number 23 of 1997 concerning Environmental Management. The case has explicitly imposed a conviction against the corporation, namely PT Dongwoo Environmental Indonesia, as the subject of a criminal act, although in the indictments and charges, the Public Prosecutor remained hesitant in declaring the corporation as a defendant, by declaring the defendant as Kim Young Woo (in this case representing PT Dongwoo Environmental Indonesia). The defendant should be PT Dongwoo Environmental Indonesia, represented by Kim Young Woo, as stated by the judicial panel in the verdict. Hence, the defendant is the corporation, PT Dongwoo Environmental Indonesia, which in the judicial process is represented by the chief of its management as the corporate organ.

Indictments, criminal charges, and convictions against corporations based on the Environmental Protection Law (Law number 23 of 1997) are possible in addition to the management. However, this is not the case with the Protection and Management of the Environment Law (Law Number 32 of 2009), which replaces Law number 23 of 1997. The former states that it is no longer possible for corporations to be prosecuted and adjudicated according to the criminal law because it seems that the legislators intended to exempt corporations from criminal responsibility and criminal imposition. The latter suggests its exemption to regulate criminal provisions for corporations. The criminal responsibility in environmental crime is bestowed in the functional management of the corporation and thus concluding the criminal responsibility for an individual.

In the 2015 Criminal Code draft, provisions relating to criminal charges against corporations have been formulated. It says that in the criminal prosecution against corporations, it must be considered whether there is another aspect of the law that can provide more useful protection than imposing criminal charges against corporations (Article 52 paragraph 1).

Based on the reality that there are very few criminal charges against corporations for corruption in the procurement of government goods or services (only three cases above), it is worth asking about the hindrance. What does result in law enforcement's ineffectiveness to charge corporations? It was found that law enforcement is unable to prove the corporations' legal responsibility to fulfill the offense requirement. It is because of the presumption of innocence, a common legal principle within the Indonesian Criminal Code.

Corporations can be indeed sentenced to the legal penalty. Criminalization against corporations, besides fines, can also be imposed even if the corporation is not accused in a quo case. In the application of proving the crime of corruption against goods or services, iudex facti and iudex juris continue to use acts against material law to deny the Constitutional Court Decision Number 003 / PU-IV / 2006 dated July 25, 2006. In essence, the illustration is one example of how challenging it is for law enforcement to charge corporations.

Corporate crime in Indonesia is still not regulated in the Criminal Code, but the formulation of corporations to commit criminal acts has been disseminated in various laws outside the Criminal Code, including the law concerning the Eradication of Corruption. The formulation is not supported by adequate formal law, but the vacancy has been filled with the Supreme Court Edict Number 13 of 2016 concerning the Procedures of Handling Crime for Corporations. However, such a legal basis is not the same as the law on the statutory level. 
Therefore, it is odd if the formulation of corporate crime regulated in the statute was supported by a statutory law regulated by a regulation inferior to the statute. It will be a resolute idea if the Supreme Court Edict immediately upgraded the edict or adopted it into the Draft Criminal Procedure Code to be effective immediately.

\section{Conclusion}

The Criminal Code does not explicitly regulate corporate crime because there is always a debate on the corporation's culpability. Adjacent to that notion, several doctrines or models can be utilized. Law Number 31 of 1999 jo. and Law Number 20 of 2001 state that corporate error regulation adheres to vicarious liability doctrine. The Criminal Procedure Code does not regulate the application and execution of corporate crimes since no formal criminal law can authorize law enforcement to charge a corporate crime other than those regulated by the relevant law. As in the Law on Corruption Eradication, formal law to eradicate corporate crime is contained in Article 20. Even so, the existing formal laws are deemed insufficient. The lack of regulation aggravates it in achieving a resolute attempt to overcome difficulties in prosecuting criminal corporations, including in cases of corruption cases by corporations. Thus, the Supreme Court has issued Supreme Court Edict Number 13 of 2016 concerning Procedures for Handling Crime by Corporations, which have filled the formal legal void.

\section{References}

[1] Jan Remmelink, Hukum Pidana, PT Gramedia Pustaka Utama, Jakarta, hlm. 99; M. Arief Amrullah, Kejahatan Korporasi, Bayumedia, Malang, 2006.

[2] Jan Remmelink, Hukum Pidana Komentar atas Pasal-pasal Terpenting dari Kitab Undang-Undang Hukum Belanda dan Padanannya dalam Kitab Undang-Undang Hukum Pidana Indonesia. Jakarta: Gramedia Pustaka Utama. 2003.

[3] Johnny Ibrahim, Teori dan Metode Penelitian Hukum Normatif, Malang: Bayu Media, 2010.

[4] Andi Hamzah, Korupsi di Indonesia Masalah dan Pemecahannya, Jakarta: Gramedia Pustaka Utama, 1988

[5] Andi Hamzah, Pemberantasan Korupsi Melalui Hukum Pidana Nasional dan Internasional, Jakarta: Raja Grafindo Persada, 2007.

[6] Barda Nawawi Arief, Bunga Rampai Kebijakan Hukum Pidana, Jakarta: Kencana Prenada Media Group, 2010

[7] Yusuf Shofie, Tanggungjawab Pidana Korporasi Dalam Hukum Perlindungan Konsumen di Indonesia, Bandung: PT. Citra Aditya Bakti, 2011

[8] Widyo Pramono. Pertanggungjawaban Pidana Korporasi Hak Cipta. Bandung: Alumni. 2013. 